\title{
Peran kader peduli stunting meningkatkan optimalisasi penurunan risiko stunting
}

\author{
Dyah Wiji Puspita Sari ${ }^{{ }^{*}}$, Apriliani Yulianti Wuriningsih ${ }^{2}$, Nopi Nur Khasanah ${ }^{3}$, Naila Najihah ${ }^{4}$ \\ ${ }^{1}$ Fakultas Keperawatan, Universitas Airlangga, Indonesia \\ 1,2,3Fakultas IImu Keperawatan, Universitas Islam Sultan Agung, Indonesia \\ ${ }^{4}$ Fakultas Ekonomi, Universitas Islam Sultan Agung, Indonesia \\ ${ }^{*}$ Coressponding Author : daiyah_04@yahoo.com
}

\begin{abstract}
Abstrak
Pendahuluan: Stunting merupakan masalah nasional yang saat ini mendapatkan perhatian khusus. Hasil Pemantauan Status Gizi pada tahun 2016 oleh Kemenkes RI menyebutkan bahwa Balita pendek dan sangat pendek jumlahnya masih banyak. Metode: Jenis penelitian ini adalah quasi eksperimental dengan rancangan one group pretest posttest. Pemilihan sampel menggunakan teknik purposive sampling pada anak berusia bawah dua tahun (baduta) di RW 1 Kelurahan Penggaron Lor Kota Semarang. Instrumen yang digunakan adalah grafik KMS dengan alat ukur Tinggi Badan dan Berat Badan yang telah dikalibrasi sebelumnya untuk mendapatkan data angka kejadian stunting yang akurat. Hasil: Hasil penelitian menunjukkan nilai $p=0,002(<0,005)$, sehingga RS AS efektif dalam optimalisasi penurunan risiko stunting. Simpulan: RS AS efektif menurunkan risiko stunting. Kerjasama lintas sectoral dan dukungan langsung dari masyarakat sangat diperlukan untuk kesinambungan program dan pendampingan ibu terutama yang memiliki baduta
\end{abstract}

Kata kunci: Rumah Sehat Anti Stunting; risiko stunting; baduta

\section{The role of the stunting care cadres increased the optimization of stunting reduction}

\begin{abstract}
Introduction: Stunting is a national problem that is currently receiving special attention. Nutrition Status Monitoring Results in 2016 by the Republic of Indonesia Ministry of Health stated that there are still many short and very short toddlers. Methods: This type of research is a quasi experimental design with one group pretest posttest. The sample selection uses a purposive sampling technique in children under two years (baduta) in RW 1, Penggaron Lor SubDistrict, Semarang City. The instrument used was a KMS chart with height and weight measurements that had been previously calibrated to obtain accurate stunting event data. Results: The results showed the value of $p=0.002$ $(<0.005)$, so that the US Hospital was effective in optimizing the risk reduction of stunting. Conclusions:The US Hospital decreased risk of stunting. Cross-sectoral collaboration and direct support from the community are needed for the sustainability of the program and the assistance of mothers, especially those who have a family member.
\end{abstract}

Keywords: Anti Stunting Health House; risk of stunting; baduta

How to Cite: Sari, WPS., Wuriningsih, AYW., \& Khasanah, NN., Najihah, N. (2021). Peran kader peduli stunting meningkatkan optimalisasi penurunan risiko stunting. NURSCOPE: Jurnal Penelitian dan Pemikiran Ilmiah Keperawatan, 7 (1), 45-52

\section{PENDAHULUAN}

Ancaman permasalahan gizi di dunia, ada 165 juta anak dibawah 5 tahun dalam kondisi pendek (stunting) dan 90\% lebih berada di Afrika dan Asia. Target global adalah menurunkan Stunting sebanyak 40\% pada tahun 2025 (Kementrian Kesehatan RI, 2016). Untuk itu dibutuhkan penurunan 3,9\% per tahun. Dalam jangka waktu 20 tahun tersebut dapat diturunkan 1,6\% per tahun. Penurunan yang cukup besar terjadi di 
Asia (dari 49\% menjadi 28\%), sekitar 2,9\% per tahun. Penurunan yang terbesar ada di Tiongkok, pada tahun 1990 sebesar 30\% menjadi 10\% pada tahun 2011. Hasil dari South East Asian Nutrition Survey (SEANUTS) pada tahun 2010-2011 menempatkan Indonesia sebagai negara yang memiliki jumlah anak balita pendek terbesar, jauh diatas Malaysia, Thailand serta Vietnam (Union, The, International, \& Consortium, 2014). Status gizi balita jawa tengah tahun 2017 berdasar PSG: Balita gizi kurang (17\%), Balita pendek (28,5\%), Balita kurus (9,3\%).

Masalah stunting salah satunya dipengaruhi oleh status gizi ibu dan anak. Status gizi dan kesehatan ibu pada masa pra-hamil, saat kehamilannya dan saat menyusui sejak 1000 hari pertama kehidupan (HPK) merupakan periode yang sangat kritis. Kekurangan gizi kronik pada 1000 HPK akan berdampak pada gangguan pertumbuhan fisik yaitu salah satunya stunting, hingga berdampak pada kualitas kerja yang tidak kompetitif yang berakibat pada rendahnya tingkat pendapatan dan kesejahteraan masyarakat (Kementerian Koordinator Bidang Kesejahteraan Rakyat, 2013; Trihono et al., 2015). Masalah kekurangan gizi atau stunting disebabkan oleh banyak faktor.

Berbagai bukti ilmiah dari lembaga riset gizi dan kesehatan terbaik di dunia menunjukkan bahwa faktor penyebab terpenting stunting adalah lingkungan hidup sejak konsepsi sampai anak usia 2 tahun yang dapat dirubah dan diperbaiki dengan fokus pada masa 1000 HPK (Barker \& Thornburg, 2013). Bukan karena faktor utama yaitu faktor genetik seperti anggapan masyarakat pada umumnya.

Masalah gizi merupakan akibat dari berbagai faktor yang saling terkait. Terdapat dua faktor langsung yang mempengaruhi status gizi individu. Faktor penyebab langsung pertama adalah konsumsi makanan yang tidak memenuhi jumlah dan komposisi zat gizi yang memenuhi syarat gizi seimbang yaitu beragam, sesuai kebutuhan, bersih, dan aman, misalnya bayi tidak memperoleh ASI Eksklusif. Faktor penyebab langsung kedua adalah penyakit infeksi yang berkaitan dengan tingginya kejadian penyakit menular terutama diare, cacingan dan penyakit pernapasan akut (ISPA) (Kementerian Koordinator Bidang Kesejahteraan Rakyat, 2013).

Masalah stunting akan terus terjadi apabila tidak ada perbaikan gizi dan pelayanan kesehatan yang memadai pada masa-masa 1000 HPK. Pentingnya pemenuhan gizi pada kelompok 1000 HPK akan mengurangi jumlah anak pendek di generasi yang akan datang dan seterusnya (Ahmed, Rahman Khan, \& Jackson, 2001; Barker \& Thornburg, 2013; International Food Policy Research Institute, 1999; Kementerian Koordinator Bidang Kesejahteraan Rakyat, 2013).

Hasil studi pendahuluan yang dilakukan oleh tim peneliti di kelurahan penggaron lor khususnya di RW 1 didapatkan data bahwa jumlah penduduk terdiri dari 5990 dengan jumlah KK 1547 dan jumlah penduduk perempuan 2857 orang (Data Demografi Kel Penggaron Lor, 2018). Berdasarkan hasil penyebaran kuesioner terkait masalah stunting didapatkan data bahwa pengetahuan ibu untuk memilih makanan dengan kadar gizi seimbang masih kurang $(28,6 \%)$, Pengetahuan ibu tentang keteraturan meminum tablet Fe masih kurang $(34,3 \%)$ dan pengetahuan ibu mengenai pemberian program tablet Fe dari puskesmas masih kurang $(28,6 \%)$.

Pengetahuan ibu mengenai pemberian MP-ASI masih kurang (31,4\%), Pengetahuan ibu untuk membawa balitanya ke posyandu masih kurang $(57,1 \%)$, Pengetahuan ibu mengenai bahan yang ditambahkan saat memakaikan popok masih kurang $(28,6 \%)$, Kepercayaan ibu mengenai makanan saat hamil masih kurang (26,67\%), Ibu menganggap menyusui memiliki efek samping terhadap perubahan payudaranya (40\%), Kepercayaan ibu terhadap pemberian madu pada usia 0-6 bulan masih kurang (22,9\%), Sikap ibu terhadap 
porsi makan saat hamil masih kurang $(31,4 \%)$, Sikap ibu membawa ke posyandu setelah imunisasi lengkap masih kurang $(34,3 \%)$, Tidak memberikan ASI eksklusif $(11,1 \%)$, Tidak menimbang balita satu bulan terakhir (48,7\%), Tidak memberikan imunisasi lengkap (37,5\%), 62,9\% kader posyandu tidak mengunjungi ibu yang mempunyai balita jika ibu balita tersebut tidak hadir dalam 3 kali posyandu berturut turut.

Salah satu upaya perbaikan dalam menangani masalah stunting adalah melalui pembentukan Rumah Anti Stunting. Rumah Anti Stunting berfokus pada pemenuhan gizi dan pembangunan lingkungan yang sadar tumbuh kembang anak pada kelompok 1000 HPK melalui pemenuhan gizi pada penyediaan pangan yang bergizi seimbang khususnya bagi ibu hamil, penyediaan makanan pendamping ASI (MP-ASI) untuk anak usia 6-23 bulan, PMT ibu hamil dan balita, edukasi ASI Eksklusif, pelayanan ANC, imunisasi, monitoring pertumbuhan balita, suplemen tablet besi-folat ibu hamil, dan hygiene ibu.

\section{METODE}

Penelitian deskriptif kuantitatif menggunakan pendekatan cross sectional. Populasinya adalah seluruh ibu yang mempunyai anak prasekolah umur 3-6 tahun di TK Lamongan. Besar sampel dalam penelitian ini sebanyak 40 responden yang diambil melalui teknik simple random sampling. Penelitian ini dilakukan pada bulan Mei-Juli 2019.

Variabel independent dalam penelitian adalah tingkat pengetahuan ibu. Variabel dependent yakni keberhasilan toilet training pada anak prasekolah. Pengumpulan data menggunakan kuesioner pengetahuan toilet training dan kuesioner keberhasilan toilet training. Analisa data dengan univariat dan uji fishers exact test $(p<0.05)$. Penelitian ini lolos kaji etik di Komisi Etik Penelitian Kesehatan Fakultas Keperawatan Universitas Airlangga No. 1676-KEPK.

\section{HASIL DAN PEMBAHASAN}

Pada tabel 1. menunjukkan bahwa sebagian besar ibu berusia $<35$ tahun, memiliki pendidikan tinggi, tidak bekerja, memiliki rata-rata pendapatan keluarga lebih dari atau sama dengan UMR, jumlah anggota keluarga kurang dari sama dengan 4, memiliki sanitasi yang baik, sebagian besar ibu memiliki IMT normal $(\geq 18,5)$, berat badan lahir bayi sebagian besar normal dan berjenis kelamin perempuan.

Tabel 1. Karakteristik responden di Kelurahan Penggaron Lor Kota Semarang November 2019 $(n=35)$

\begin{tabular}{llcc}
\hline No & \multicolumn{1}{c}{ Variabel } & N & \% \\
\hline 1. & Usia Ibu & & \\
& $<35$ tahun & 29 & 82,9 \\
& $>=35$ tahun & 6 & 17,1 \\
\hline 2. & Status Pendidikan Ibu & & \\
& Pendidikan rendah (SD, SMP) & 9 & 25,7 \\
& Pendidikan tinggi (SMA, PT) & 26 & 74,3 \\
\hline 3. & Status Pekerjaan Ibu & & \\
& Tidak bekerja & 21 & 60 \\
& Bekerja & 14 & 40 \\
\hline 4. & Status Pendapatan Keluarga & & \\
& $>=$ UMR & 28 & 20 \\
& $<$ UMR & 7 & \\
\hline 5. & Jumlah Anggota Keluarga & 7 & 97 \\
& $<=4$ & 34 & 3 \\
\hline
\end{tabular}




\begin{tabular}{|c|c|c|c|}
\hline No & Variabel & $\mathbf{N}$ & $\%$ \\
\hline \multirow[t]{3}{*}{6.} & Sanitasi & & \\
\hline & Baik & 34 & 97 \\
\hline & Tidak & 1 & 3 \\
\hline \multirow[t]{3}{*}{7.} & IMT Ibu & & \\
\hline & $>=18,5$ & 34 & 28,6 \\
\hline & $<18,5$ & 1 & 71,4 \\
\hline \multirow[t]{3}{*}{8.} & Berat badan lahir & & \\
\hline & $<2500$ gram & 3 & 8,6 \\
\hline & $\geq 2500$ gram & 32 & 91,4 \\
\hline \multirow[t]{3}{*}{9.} & Jenis Kelamin Bayi & & \\
\hline & Laki-laki & 16 & 45,7 \\
\hline & Perempuan & 19 & 54,3 \\
\hline
\end{tabular}

Hasil uji Wilcoxon pada tabel 2 menunjukkan bahwa nilai $p=0,001$, sehingga terdapat perbedaan risiko stunting sebelum dan setelah mengikuti program Rumah Sehat anti Stunting (RS AS).

Tabel 2. Perbedaan risiko stunting sebelum dan setelah mengikuti program RS AS, November 2019 $(n=35)$

\begin{tabular}{|c|c|c|c|c|c|}
\hline \multirow{2}{*}{ Risiko Stunting } & \multicolumn{2}{|c|}{ Pre Intervensi } & \multicolumn{2}{|c|}{ Post Intervensi } & \multirow{2}{*}{ Nilai $p$} \\
\hline & $\mathrm{n}$ & $\%$ & $\mathbf{n}$ & $\%$ & \\
\hline Stunting & 6 & 17,1 & 4 & 11,4 & \multirow{4}{*}{0,002} \\
\hline Risiko Stunting & 8 & 22,9 & 2 & 5,7 & \\
\hline Tidak Berisiko & 21 & 60 & 29 & 82,9 & \\
\hline Total & 35 & 100 & 35 & 100 & \\
\hline
\end{tabular}

Proses monitoring tumbuh kembang anak usia di bawah dua tahun pada penelitian ini dilakukan selama 12 minggu. Pada 4 minggu pertama dilakukan pelatihan terhadap pengetahuan dan keterampilan kader kesehatan peduli stunting oleh tim Rumah sehat anti stunting. Kemudian melalui pemberdayaan peran kader kesehatan peduli stunting melakukan pendampingan pada orang tua yang memiliki anak usia di bawah dua tahun (Baduta) secara langsung dalam pencegahan terhadap risiko stunting. Monitoring BB bayi diukur mulai minggu ke 5, 9, dan 12, selama minggu-minggu tersebut ibu didampingi oleh kader dan mengikuti program pencegahan dan penanganan stunting bekerjasama dengan RS AS. Hasil penelitian menunjukkan bahwa terdapat perbedaan ririko stunting setelah mengikuti program RS AS, hasil uji nilai $p$ $=0,001(<0,005)$.

RA AS berfokus pada pemenuhan gizi dan pembangunan lingkungan yang sadar tumbuh kembang anak pada kelompok 1000 HPK melalui pemenuhan gizi pada penyediaan pangan yang bergizi seimbang khususnya bagi ibu hamil, penyediaan makanan pendamping ASI (MP-ASI) untuk anak usia 6-23 bulan, PMT ibu hamil dan balita, edukasi ASI Eksklusif, pelayanan ANC, imunisasi, monitoring pertumbuhan balita, suplemen tablet besi-folat ibu hamil, dan hygiene ibu.

Hasil penelitian menunjukkan bahwa RS AS efektif terhadap optimalisasi penurunan risiko stunting di Kelurahan Penggaron Lor Kota Semarang. Hal ini menunjukkan bahwa Kader kesehatan peduli stunting memiliki kontribusi yang besar terhadap penurunan risiko stunting setelah melalui proses pelatihan meningkatkan pengetahuan dan keterampilan dalam melakukan pendampingan untuk mencegah risiko stunting mulai dari masa pra konsepsi, antenatal, sampai pada Baduta. 
Stunting merupakan kondisi status gizi berdasarkan panjang atau tinggi badan menurut umur bila dibandingkan dengan standar baku WHO-MGRS (Multicentre Growth Reference Study) tahun 2005, dengan nilai z-score kurang dari-2SD (Kementrian Kesehatan, 2011). Hasil penelitian menunjukkan bahwa pengetahuan dan motivasi kader kesehatan berpengaruh terhadap kinerja Kader dalam pencegahan stunting (Afifa, 2019). Menurut Ngaisyah \& Adiputra (2018) Kader posyandu mampu melaksanakan perannya dengan terampil, meliputi penyuluhan pola kesehatan dan konsumsi gizi mulai periode kehamilan dan monitoring status stunting balita sebagai upaya penurunan stunting setelah diberikan pelatihan dan pendampingan oleh professional kesehatan yang fokus terhadap pencegahan stunting.

Hasil penelitian menunjukkan bahwa nutrisi ibu yang optimal harus sangat didukung bahkan sebelum konsepsi, karena sangat berpengaruh terhadap pertumbuhan janin yang optimal di dalam rahim (Vir, 2016; Young et al., 2018). Ibu hamil yang mengonsumsi suplemen zat besi atau asam folat atau suplementasi mikronutrien multipel dapat meningkatkan pertumbuhan janin, panjang lahir dan pertumbuhan postnatal (Young et al., 2018). Ada hubungan yang kuat antara stunting dan konsumsi protein hewani (Young et al., 2018). Selain itu, pendidikan gizi dan konseling selama kehamilan dilengkapi dengan dukungan gizi dapat meningkatkan berat badan lahir, yang penting untuk proses pertumbuhan anak (Black \& Heidkamp, 2018; Titaley, Ariawan, Hapsari, Muasyaroh, \& Dibley, 2019). Selain itu, strategi pendidikan untuk mempromosikan konsumsi makronutrien selama kehamilan penting untuk diperhatikan. Pemberian suplementasi protein seimbang terutama di kalangan perempuan kurang gizi dapat meningkatkan pertumbuhan janin (Black \& Heidkamp, 2018; Young et al., 2018).

Petugas atau kader kesehatan dapat mempromosikan pemanfaatan layanan perawatan antenatal bagi ibu dan bayi. Banyaknya kontak selama kunjungan antenatal menyebabkan jadwal pemeriksaan ibu menjadi teratur dan berulang dengan petugas kesehatan dan peluang untuk sesi pendidikan kesehatan secara interaktif dapat dilakukan. Dengan memiliki perawatan antenatal yang memadai, ibu akan dapat meningkatkan pengetahuan tentang pemberian makanan yang sesuai untuk bayi mereka setelah melahirkan, termasuk menyusui dan pemberian makanan tambahan (Black \& Heidkamp, 2018; Gupta, Suri, Dadhich, Trejos, \& Nalubanga, 2019; Young et al., 2018). Ibu juga dapat memiliki kesempatan untuk menerima informasi tentang penyakit dan infeksi pada anak dan bagaimana mencegahnya. Kehadiran yang cukup di ANC juga berkaitan dengan sikap ibu dalam memberikan perawatan yang optimal setelah melahirkan, sehingga pertumbuhan dan kesejahteraan anak akan tercapai secara maksimal.

Proses pemantauan pertumbuhan balita di posyandu merupakan upaya untuk mendeteksi dini terjadinya gangguan pertumbuhan. Pencegahan dini adalah salah satu cara terbaik untuk mengurangi prevalensi stunting. Prosedur terpenting dari pencegahan dini adalah dilakukan screening rutin dan follow-up tinggi badan balita yang persisten. Program Posyandu menjadi solusi yang konkrit untuk menjangkau seluruh lapisan masyarakat. Semakin baik pelayanan yang dilakukan posyandu sebanding dengan peningkatan mutu kesehatan masyarakat. Proses screening rutin tinggi badan/umur sudah menjadi agenda wajib dalam setiap kegiatan yang dilaksanakan di posyandu (Setyowati \& Astuti, 2015).

Kegiatan pelatihan yang diberikan kepada para kader kesehatan memberikan pengaruh terhadap peningkatan pengetahuan para kader kesehatan. Metode yang diberikan pada kegiatan ini antara lain ceramah dan diskusi, simulasi serta praktikum. Hasil penelitian Sarwani, Nurhayati, \& Supriyanto (2014) menunjukkan bahwa terdapat perbedaan pengetahuan kader kesehatan sebelum dan sesudah diberikan pelatihan atau pendampingan. 
Peningkatan pengetahuan kader kesehatan dapat meningkatkan rasa percaya diri maupun sikap perilaku seseorang, sehingga pengetahuan bisa mendorong terbentuknya tindakan seseorang untuk melakukan perubahan menjadi lebih baik (Notoatmodjo, 2012). Hasil penelitian menunjukkan bahwa perilaku didasari oleh tingkat pengetahuan. Penelitian yang dilakukan oleh Fatmah \& Nasution (2012) menyimpulkan bahwa tingkat keterampilan kader kesehatan berhubungan dengan peningkatan pengetahuan sebelum dan setelah pelatihan.

Peran aktif kader kesehatan dalam deteksi dini stunting dan stimulasi tumbuh kembang pada anak menurut Adistie, Lumbantobing, \& Maryam (2018) memberikan kontribusi atas terwujudnya peningkatan derajat kesehatan masyarakat. Proses pelaksanaan pendampingan oleh kader kesehatan juga bekerjasama dengan pihak puskesmas dan dinas terkait untuk melakukan pelaporan Anak dengan stunting atau berisiko stunting, serta anak dengan risiko penyimpangan atau gangguan tumbuh kembang dapat segera mendapatkan penanganan dengan cepat dan tepat sehingga dapat membantu mencegah atau meminimalisir dampak yang merugikan pada anak maupun keluarga serta menurunkan angka morbiditas. di wilayah tersebut.

\section{SIMPULAN DAN SARAN}

Hasil penelitian menunjukkan bahwa RS AS efektif terhadap optimalisasi penurunan risiko stunting di Kelurahan Penggaron Lor Kota Semarang. Hal ini dapat di implikasikan bahwa adanya kegiatan peningkatan pengetahuan, sikap, dan ketrampilan kader kesehatan dalam mencegah risiko stunting melalui kerjasama dengan berbagai pihak terutama Puskesmas Kecamatan Bangetayu dalam hal edukasi berkelanjutan; monitoring dan evaluasi yang dilakukan secara rutin oleh pihak puskesmas terhadap para kader kesehatan dalam pelaksanaan penimbangan, deteksi status gizi maupun deteksi serta stimulasi tumbuh kembang anak; optimalisasi pelaporan seperti cara pencatatan yang efektif dan jelas disertai hasil interpretasi pengukuran serta kecepatan dalam penyerahan laporan hasil deteksi dini tumbuh kembang anak serta status gizi dan deteksi stunting dari para kader kesehatan kepada bidan desa setempat atau puskesmas, dan pemberian reward kepada kader kesehatan yang berperan aktif dalam melakukan deteksi dini stunting serta deteksi dini dan stimulasi tumbuh kembang anak sehingga dapat memotivasi kader kesehatan lain dalam meningkatkan performanya.

\section{DAFTAR PUSTAKA}

Adistie, F., Lumbantobing, V., \& Maryam, N. (2018). Pemberdayaan Kader Kesehatan Dalam Deteksi Dini Stunting dan Stimulasi Tumbuh Kembang pada Balita. Media Karya Kesehatan, 1(2), 173-184. https://doi.org/10.24198/mkk.v1i2.18863

Afifa, I. (2019). Kinerja Kader dalam Pencegahan Stunting : Peran Lama Kerja sebagai Kader, Pengetahuan dan Motivasi. Jurnal Kedokteran Brawijaya, 30(4), 336-341.

Ahmed, F., Rahman Khan, M., \& Jackson, A. A. (2001). Concomitant supplemental vitamin A enhances the response to weekly supplemental iron and folic acid in anemic teenagers in urban Bangladesh. American Journal of Clinical Nutrition, 74(1), 108-115.

Aridiyah, F., Rohmawati, N., \& Ririanty, M. (2015). Faktor-faktor yang memengaruhi kejadian stunting pada anak balita di wilayah Pedesaan dan Perkotaan. E-Jurnal Pustaka Kesehatan, 3(1), 163-170.

Aryastami, N., \& Tarigan, I. (2017). Kajian Kebijakan dan Penanggulangan Masalah Gizi Stunting di 
Indonesia. Buletin Penelitian

https://doi.org/10.22435/bpk.v45i4.7465.233-240

Kesehatan, $\quad 45(4)$,

233-240.

Barker, D. J. P., \& Thornburg, K. L. (2013). Placental programming of chronic diseases, cancer and lifespan: A review. Placenta, 34(10), 841-845. https://doi.org/10.1016/j.placenta.2013.07.063

Black, R., \& Heidkamp, R. (2018). Causes of stunting and preventive dietary interventions in pregnancy and early childhood. Nestle Nutrition Institute Workshop Series, 89, 105-113. https://doi.org/10.1159/000486496

Fatmah, \& Nasution, Y. (2012). Media Medika. Pemberian Cairan Karbohidrat Elektrolit, Status Hidrasi Dan Kelelahan Pada Pekerja Wanita, 46(14), 6-11.

Gupta, A., Suri, S., Dadhich, J. P., Trejos, M., \& Nalubanga, B. (2019). The World Breastfeeding Trends Initiative: Implementation of the Global Strategy for Infant and Young Child Feeding in 84 countries. Journal of Public Health Policy (Vol. 40). Palgrave Macmillan UK. https://doi.org/10.1057/s41271018-0153-9

International Food Policy Research Institute. (1999). Eradicating Malnutrition: Income Growth or Nutrition Programs?

Kementerian Koordinator Bidang Kesejahteraan Rakyat. (2013). Kerangka Kebijakan Gerakan Nasional Percepatan Perbaikan Gizi dalam Rangka Seribu Hari Pertama Kehidupan (Gerakan 1000 HPK), 71.

Kementrian Kesehatan. (2011). Standar Antropometri Penilaian Status Gizi Anak. Standar Antropometri Penilaian Status Gizi Anak. Jakarta: Kementerian Kesehatan RI.

Kementrian Kesehatan RI. (2016). Situasi balita pendek. Info Datin, 2442-7659. https://doi.org/ISSN 24427659

Kusumawati, E., Rahardjo, S., \& Sari, H. (2015). Model Pengendalian Faktor Risiko Stunting pada Anak Usia di Bawah Tiga Tahun. Jurnal Kesehatan Masyarakat, 9(3), 249-256.

Mitra, M. (2015). Permasalahan Anak Pendek (Stunting) dan Intervensi untuk Mencegah Terjadinya Stunting (Suatu Kajian Kepustakaan). Jurnal Kesehatan Komunitas, 2(6), 254-261. https://doi.org/10.25311/jkk.vol2.iss6.85

Ngaisyah, R., \& Adiputra, A. (2018). Pemberdayaan Kader Posyandu untuk Perbaikan Pola KOnsumsi terhadap Nugget Ikan dan Abon Ikan sebagai Alternatif Penurunan Stunting Balita di Desa Kanigoro, Saptosari, Gunungkidul. In Prosiding Seminar Nasional Seri 8 (pp. 217-226).

Notoatmodjo, S. (2012). Promosi Kesehatan \& Perilaku. Jakarta: Rineka Cipta (Vol. 1). Jakarta: Rineka Cipta.

Paramashanti, B., Paratmanitya, Y., \& Marsiswati, M. (2017). Individual dietary diversity is strongly associated with stunting in infants and young children. Jurnal Gizi Klinik Indonesia, 14(1), 19. https://doi.org/10.22146/ijcn.15989 
Rosmalina, Y., Luciasari, E., \& Ernawati, F. (2018). Upaya Pencegahan dan Penanggulangan Batita Stunting: Systematic Review. Gizi Indononesia, 41(1), 1-14. Retrieved from http://ejournal.persagi.org/index.php/Gizi_Indon

Sarwani, D., Nurhayati, N., \& Supriyanto. (2014). Efektifitas Ceramah terhadap Pengetahuan Kader Kesehatan tentang Penyakit Talasemia di Kecamatan Pekuncen dan Kecamatan Sumbang Kabupaten Banyumas. Jurnal Kesehatan Masyarakat (Journal of Public Health), 8(1). https://doi.org/10.12928/kesmas.v8i1.1038

Setiawan, E., Machmud, R., \& Masrul, M. (2018). Faktor-faktor yang berhubungan dengan kejadian stunting pada anak usia 24-59 bulan di wilayah kerja Puskesmas Andalas Kecamatan Padang Timur Kota Padang Tahun 2018 Eko. Jurnal Kesehatan Andalas, 7(2), 275-284.

Setyowati, M., \& Astuti, R. (2015). Pemetaan Status Gizi Balita dalam Mendukung Keberhasilan Pencapaian Millenium Development Goals (MDGs). Jurnal Kesehatan Masyarakat, 10(2), 110-121. Retrieved from file://C:/Users/user/Downloads/1854-4349-2-PB.pdf

Subagyo, W., \& Wahyuningsih, D. (2015). Peran Kader Dalam Memotivasi Ibu Balita Berkunjung Ke Posyandu. Soedirman Journal of Nursing, 10(3), 158-166.

Titaley, C., Ariawan, I., Hapsari, D., Muasyaroh, A., \& Dibley, M. (2019). Determinants of the stunting of children under two years old in Indonesia: A multilevel analysis of the 2013 Indonesia basic health survey. Nutrients, 11(5). https://doi.org/10.3390/nu11051106

Trihono, Atmarita, Tjandrarini, D. H., Irawati, A., Utami, N. H., Tejayanti, T., \& Nurlinawati, I. (2015). Pendek (Stunting) di Indonesia, Masalah dan Solusi. Lembaga Penerbit Balitbangkes.

Triyanti, M., Widagdo, L., \& Syamsulhuda, B. (2017). Peningkatan Pengetahuan dan Ketrampilan Kader Pemantauan Tumbuh Kembang Balita di Posyandu dengan Metode BBM dan Mind Mapping (MM). Jurnal Promosi Kesehatan Indonesia, 12(2), 265. https://doi.org/10.14710/jpki.12.2.265-277

Unicef. (2013). Improving child nutrition. NCSL legisbrief (Vol. 18). Unicef.

Union, E., The, A. G., International, A. C. E., \& Consortium, C. (2014). Education Sector - Analytical and Capacity Development Partnership Indonesia Mid-term Review Final Report, (October), 1-56.

Vir, S. (2016). Improving women's nutrition imperative for rapid reduction of childhood stunting in South Asia: Coupling of nutrition specific interventions with nutrition sensitive measures essential. Maternal and Child Nutrition, 12, 72-90. https://doi.org/10.1111/mcn.12255

Young, M., Nguyen, P., Gonzalez Casanova, I., Addo, O., Tran, L., Nguyen, S., ... Ramakrishnan, U. (2018). Role of preconception nutrition in offspring growth and risk of stunting across the first 1000 days in Vietnam. PloS One, 71(Supplement 2), 538. https://doi.org/10.1159/000480486 